JURNAL PUBLIPRENEUR: POLITEKNIK NEGERI MEDIA KREATIF

Vol. 8, No. 2, December 2020, hal. 45-56

Submitted: 1 December 2020

Revised: 10 December 2020

Accepted: 20 December 2020

\title{
BOOK ANALYSIS WITH THEMA GEOPOLITICS "MEDIA, TERRORISM AND THEORY”, A CRITICAL THEORY RESEARCH APPROACH USING SEMIOTIC ANALYSIS
}

\author{
Deddy Stevano H. Tobing1, Henny Saptatia ${ }^{2}$ \\ Universitas Indonesia ${ }^{12}$ \\ E-mail: $\underline{\text { deddy.stevano@ui.ac.id }}{ }^{1}$, $\underline{\text { henny.saptatia@ui.ac.id }}{ }^{2}$
}

\begin{abstract}
This article seeks to create a discussion space related to the Media Book, Terrorism and Theory. This book seeks to provide an understanding of the contextualization of the global cycle of violence within the framework of "military action" and "terrorism," as well as mass communication media. The author tries to view this book as a literary work by using semiotic analysis to get the meanings in this book, especially in the sections Critical Media Theory, Democratic Communication, and Global Conflict and Chapter 8 with the title Terrorism, Public Relations and Propaganda. This research finally succeeded in achieving an evaluation that some myths were generated from the meaning of denotation and connotation of Roland Barthes' semiotic technique. These myths when tested through the source triangulation technique show inconsistencies. Some of the myths are discussed by academics and the media, but some do not appear in the media.
\end{abstract}

Keywords: Media Literacy, Propaganda, Semiotics

\section{Analisis buku bertemakan Geopolitik "Media, Terrorism and Theory" penelitian teori kritis menggunakan analisa semiotika}

\begin{abstract}
Artikel ini berupaya menciptakan ruang diskusi terkait Buku Media, Terrorism and Theory. Buku ini berupaya untuk memberikan pengertian tentang kontekstualisasi siklus kekerasan di global dalam bingkai "aksi militer" dan "terorisme," serta media komunikasi massa. Penulis berupaya memandang buku ini seperti layaknya karya sastra dengan menggunakan analisa semiotika untuk mendapatkan makna-makna dalam buku ini khususnya pada bagian Critical Media Theory, Democratic Communication, and Global Conflict dan Bab 8 dengan judul Terrorism, Public Relations and Propaganda. Penelitian ini pada akhirnya berhasil mencapai evaluasi bahwa beberapa mitos yang dihasilkan dari pemaknaan denotasi dan konotasi dari Teknik semiotika Roland Barthes. Mitos-mitos tersebut ketika diuji melalui Teknik triangulasi sumber menunjukkan inkonsistensi. Sebagian mitos dibicarakan oleh akademisi maupun media namun Sebagian juga tidak muncul di media.
\end{abstract}

Keyword: Media Literasi, Propaganda, Semiotika 
JURNAL PUBLIPRENEUR: POLITEKNIK NEGERI MEDIA KREATIF

Vol. 8, No. 2, December 2020, hal. 45-56

Submitted: 1 December 2020

Revised: 10 December 2020

Accepted: 20 December 2020

\section{Pendahuluan}

Geopolitik adalah suatu definisi yang lazim dikenal sebagai kajian politik yaitu berhubungan dengan pengaruh dan kekuasan dalam ruang lingkup kewilayahan. Dalam kaitannya pada buku Media, Terrorism and Theory maka didapatkan pandangan-pandangan terkait terorisme media dan teorinya bagaimana berkembangnya teori media dan terorisme yang begitu mempengaruhi politik dunia saat ini. Meskipun buku ini tidak membahas geopolitik secara terpisah secara classical namun dapat dipandang telaah dibuku ini merupakan pandangan telaah critical geopolitics dan selain itu buku juga merupakan bagian dari sudut pandang popular geopolitics. Istilah geopolitics sendiri adalah istilah yang digunakan masyarakat negara-negara adidaya dalam menggambarkan situasi di dunia terkait wilayah, kekuatan dan teknologi (Tuathail. 1996 P.12). Istilah critical geopolitic muncul akibat adanya keragu-raguan memposisikan geopolitik dengan adanya pandangan kontekstual lama geopolitics yang kemudian dikaitkan dengan hal-hal yang baru seperti kapitalisme, environmentalism, ras, politik wilayah perkotaan dan perfilman (Tuathail. Ibid P.49). Sedangkan sudut pandang popular geopolitics meskipun awalnya dipandang sebelah mata namun popular geopolitics dapat memberikan sumbangsih dalam memahami hubungan elit-elit politisi, media dan public umumnya terhadap kebijakan publik, multikulturalisme, identitas, hubungan antara negara,soft power dan hubungan antara agama dan negara (Pickering. 2017. P. 87). Tema-tema seperti buku ini kedepannya tentunya akan semakin marak baik dalam bentuk media cetak maupun media elektronik maka ada pentingnya dilakukan telaah secara kritis terhadap buku bertema seperti ini karena berhubungan dengan hajat masyarakat banyak.

Buku Media, Terrorism and Theory ditulis pada tahun 2006. Buku ini bukanlah buku dengan seorang pengarang tunggal melainkan setiap babnya ditulis oleh pengarang yang berbeda-beda. Sehingga isi dalam buku ini dapat dibahas secara terpisah. Artikel ini akan membahas dua hal: pertama-tama adalah Critical media consciousness dan kedua adalah terrorism, public relation dan propaganda. Kedua hal ini merupakan bagian dari buku Media, Terrorism and Theory. Sebuah buku kajian kritis media yang diterbitkan pada tahun 2006 oleh Rowman \& Littlefield publishers. Penulis dalam hal ini akan membahas dua bab yaitu Bab 7 dengan judul Critical Media Theory, Democratic Communication, and Global Conflict dan Bab 8 dengan judul Terrorism, Public Relations and Propaganda.

Pertimbangan penulis dalam pemilihan bab 7 Critical Media Theory, Democratic Communication dan bab 8 Terrorism, Public Relations, and Propaganda sebagai objek analis karena penulis melihat masih perlunya pandangan baru untuk memahami hubungan antara terorisme dan media selain itu juga memahami persepsi masyarakat global terhadap pemaknaan arti propaganda dan public relations. Dalam hal ini penulis mencoba melakukan kajian menggunakan Teknik analisa semiotika yang dikembangkan oleh filsuf prancis Roland Barthes yang mengembangkan konsep semiologi dari filsuf prancis lainnya Ferdinand de Saussure.

Untuk memperkuat validitas dari penelitian ini maka akan dilakukan triangulasi penelitian maka penulis akan menggunakan sumber dari jurnal penelitian yang 


\section{JURNAL PUBLIPRENEUR: POLITEKNIK NEGERI MEDIA KREATIF Vol.x, No. x, xxx 20xx, Doi: https://doi.org/.xxxxx, hal. $x-x x$}

membahas penelitian yang sejenis terdahulu dan referensi dari internet lainnya terkait objek penelitian seperti pemberitaan ataupun aturan-aturan yang berlaku. Triangulasi bukan merupakan cara untuk mencari kebenaran melainkan untuk meningkatkan pemahaman terhadap data dan fakta yang dimilikinya (Bachri, 2010. Hlm 55.)

\section{Tinjauan Teoritis}

Empat alternatif yang lazim dilakukan untuk penelitian untuk mendapatkan pengetahuan adalah: Melalui pengalaman pribadi dan akal sehat, pendapat para pakar dan naras umber, pesan-pesan media yang populer dan keyakinan dan nilai-nilai ideologis (Neuman, 2013. Hlm. 3). Cara penelitian yang menggunakan tumpuan pada para pakar memiliki beberapa keterbatasan dan cenderung untuk menakar kemampuan seorang pakar terlalu tinggi. Mungkin saja pakar mengutarakan bidang-bidang yang sedikit mereka ketahui atau juga bisa saja mereka salah bahkan mengatakan sesuatu yang melebihi kepakarannya dalam bidang tersebut. Sehingga seorang peneliti sebaiknya memilki pola pikir yang independent dan mengevaluasi penelitian yang kuat dari yang lemah (Neuman ibid. Hlm. 6).

Dalam mengevaluasi suatu penelitian maka diperlukan suatu paradigma. Paradigma merupakan suatu bagian pendekatan dalam penelitian disamping program penelitian dan tradisi penelitian. Dalam ilmu sosial terdapat tiga pendekatan Ilmu sosial positivis yang menekankan positivisme, kemudian ilmu sosial interprettif, dan ilmu sosial kritis (Neuman ibid Hlm. 107-123)

Ilmu sosial kritis terkait erat pandangan dengan tokoh-tokoh teori kritis yang mengkritik positivisme sebagai ilmu yang picik, antidemokrasi dan non humanis dalam penggunaan nalarnya. Pemikiran terkenal teori kritis dapat ditemui di "Sociology and Empirical Research" dan "The logic of social sciences" (1976) dari Adorno, "Knowledge and Human Interests" (1971) dari Habermas, dan "Outline of Theory of Practice" (1977) Piere Bourdieu. Bordieu berpendapat bahwa penelitian sosial harus bersifat refleksif (misalnya mempelajari dan mengkritik diri sendiri sama seperti materi yang diamati) dan perlu bersifat politis. (Neuman ibid Hlm. 123)

Pola pandang teori kritis selain menggunakan deduksi dan induksi tetapi juga menggunakan abduksi yaitu pembentukan teori dengan kerangka alternatif yang diterapkan pada data dan teori yang dijelaskan sebagai alternatif dan dievaluasi (Neuman ibid Hlm. 127)

Dalam penelitian ini yang membahas obyek penelitian teks bab 7 dan bab 8 dari buku "Media, Terrorism and Society" maka akan cocok menggunakan pisau analisis yang mendalami pemaknaan tulisan dan bahasa. Khusus untuk itu terdapat Analisa Semiotika adalah sebagai ilmu yang mempelajari tentang tanda (sign), berfungsinya tanda, dan produksi makna (Mudjiyanto \& Nur. 2013 Hlm. 73)

\section{Metode penelitian}

Metode penelitian yang digunakan adalah semiotika. Kata semiotics berakar dari bahasa yunani. Semeion yang berarti tanda. Semiotika adalah ilmu yang mempelajari tanda. Semiotik muncul karena adanya ketidakpuasan pada pendekatan struktural. Cara pendekatan semiotik memiliki sistem tersendiri yang merupakan bagian kombinasi dari tanda dan kode. Kode bisa bersifat tanda dan mempunyai banyak interpretasi makna .

Salah satu tokoh semiotik terkenal adalah 


\section{JURNAL PUBLIPRENEUR: POLITEKNIK NEGERI MEDIA KREATIF Vol.x, No. x, xxx 20xx, Doi: https://doi.org/.xxxxx, hal. $x-x x$}

Submitted: xx July 2020

Revised: xx July 2020

Accepted: xx July 2020

Ferdinand de Saussure (1857-1913) ia dikenal sebagai pemikir pertama ilmu semiotika. Saussure menggunakan istilah semiologi (Sukyadi. 2013 Hlm. 2) Pemikiran awal dari Saussure menjadi titik awal pengembangan semiotika. Kata semiotik tidak lepas dari Charles Sander Pierce (1839-1913).

Pierce menilai ada tiga jenis tanda, yaitu:

1. Icon. tanda yang mempunyai arti yang sama seperti obyek di tunjuk.

2. Indeks. tanda yang memilki hubungan sebab akibat dengan yang di tandakan

3. Simbol. tanda yang memiliki makna dengan yang di tandakan bersifat sesuai dengan persetujuan dari sebuah lingkungan sosialnya.

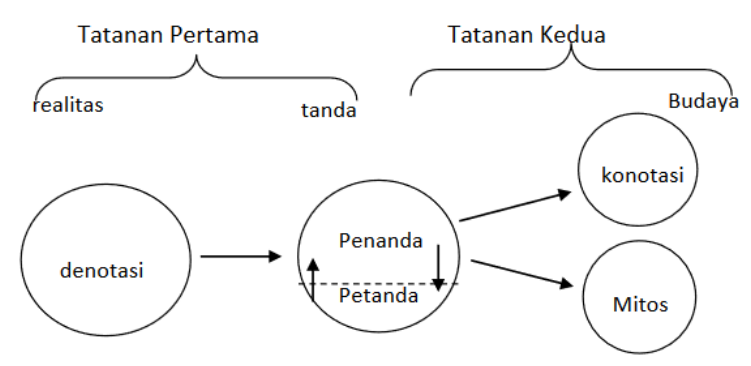

\section{Gambar 1: Semiotika Roland Barthes} (Sudarto, Senduk \& Rembang. ibid)

Metode triangulasi digunakan untuk memperkuat validitas hasil analisa, pada metode triangulasi terdapat berbagai macam satu diantaranya adalah triangulasi sumber, yang mencek Kembali derajat validitas melalui berbagai sumber (Bachri, ibid. Hlm 56.)

Kemudian adalah Roland Barthes yang mengimplentasikan teori semiotika Ferdinand de Saussure. Konsep semiotika menurut Roland Barthes (1915-1980) dibagi menjadi 2 tingkatan pertandaan, (1) denotasi, (2) konotasi. Menurut KBBI denotasi adalah makna kata atau kelompok kata yang didasarkan atas penunjukan yang lugas pada sesuatu di luar bahasa atau yang didasarkan atas konvensi tertentu dan bersifat objektif sedangkan konotasi adalah tautan pikiran yang menimbulkan nilai rasa pada seseorang ketika berhadapan dengan sebuah kata; makna yang ditambahkan pada makna denotasi (KBBI, 2020).

Pemaknaan oleh Barthes juga muncul melalui aspek lain yaitu "mitos". "Mitos" merupakan lanjutan penandaan yang akan kembali menjadi penanda yang memiliki ciri dari petanda kedua. Artinya suatu tanda dengan makna konotasinya akan berkembang menjadi makna denotasi, dan makna denotasi tersebut akhirnya menjadi mitos (Sudarto, Senduk \& Rembang, 2015).

\section{Hasil penelitian}

Analisa semiotika penelitian ini dibagi menjadi dua bagian. Bagian pertama membahas bab 7 Critical Media Theory, Democratic Communication dan kemudian membahas bab 8 terrorism, Public Relations, and Propaganda. Dari keseluruhan tiap bab akan dipilah berbagai pandangan yang ditulis oleh penulis bab itu langsung. Dalam hal ini Bab 7 ditulis oleh Todd Fraley dan Elli Lester Roushanzamir dan Bab 8 ditulis oleh Nancy snow.

\section{Analisa Semiotika pada bab 7 Critical Media Theory, Democratic Communication}

Mengenai penulis bab tersebut Todd Fraley dan Elli Lester Roushanzamir didapatkan dari sumber internet adalah sebagai berikut:

1) Todd Fraley Todd adalah seorang Associate Professor, Koordinator Studi Sarjana dan Direktur Magang di East Carolina University (East Carolina University. 2020). 
JURNAL PUBLIPRENEUR: POLITEKNIK NEGERI MEDIA KREATIF Vol.x, No. x, xxx 20xx, Doi: https://doi.org/.xxxxx, hal. $x-x x$

Submitted: xx July 2020

Revised: xx July 2020

Accepted: xx July 2020

2) Elli Lester Roushanzamir adalah seorang Associate Professor di Departemen Periklanan \& Hubungan Masyarakat Sekolah Tinggi Jurnalisme \& Komunikasi Massa University of Georgia, Athens (Academia. 2020)

Kutipan (1) (Fraley \& Roushanzamir, 2013, Hlm. 125)

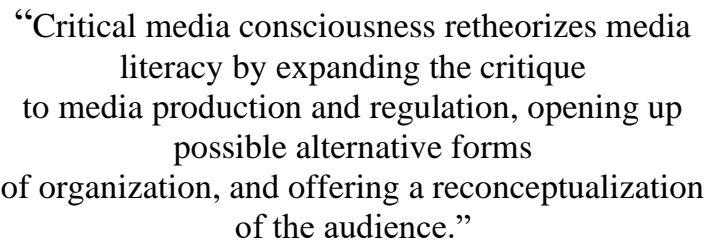

\section{Makna Denotasi:}

Para penulis Todd Fraley dan Elli Lester Roushanzamir menjelaskan konsep bernama "Critical Media Consciousness" yang menkonsep kembali media literasi dengan cara memfokuskan mengembangkan kritik pada produksi media, aturan-aturannya serta membuka bentuk alternatif dari organisasi dan menawarkan konsep ulang dari konsumen media.

\section{Makna konotasi:}

Pada tulisan ini mengkonotasikan kritik terhadap konsep Media literasi dengan berusaha menawarkan bentuk baru dari media literasi yang sudah ada.

Mitos:

Konsep media literasi dirasa masih belum cukup kuat memenuhi kebutuhan masyarakat saat ini sehingga diperlukan alternatif baru dengan mengkonsep kembali teori media literasi.

Kutipan (2) (Fraley \& Roushanzamir, ibid, Hlm. 126)
"However, as media saturate contemporary societies, becoming influential

consciousness industries and therefore influencing politics and culture as

well as the economy, communication technologies may serve different social groups."

Makna Denotasi:

Para penulis Todd Fraley dan Elli Lester Roushanzamir menyampaikan bahwa media telah memenuhi ruang hidup masyarakat saat ini. Media menjadi industry yang mempengaruhi kesadaran masyarakat sehingga mempengaruhi politik, budaya dan ekonomi.

Makna konotasi:

Pada tulisan ini mengkonotasikan bahwa media menjadi obyek yang sangat mempengaruhi kesadaran masyarakat dan bermakna strategis.

Mitos:

Media menjelma menjadi sebuah kekuatan yang sangat berperan strategis di tengah masyarakat yang perannya diperebutkan oleh banyak pihak.

Kutipan (3) (Fraley \& Roushanzamir, ibid, Hlm. 127)

"Critical media consciousness broadens "media literacy" by fostering a critique of production, distribution, and regulation as well as media content. Critical media consciousness

can contribute to an ideology of resistance and agency on the part of the heretofore dispossessed." Makna Denotasi:

Para penulis Todd Fraley dan Elli Lester Roushanzamir menyampaikan bahwa "Critical media consciousness" mengembangkan literasi media dengan memperkuat kritik terhadap produksi, aturan serta konten di media. "Critical media consciousness" dapat berkontribusi terhadap pembentukan ideologi perlawanan dan agen dari pihak-pihak yang merasa terampas 
JURNAL PUBLIPRENEUR: POLITEKNIK NEGERI MEDIA KREATIF Vol.x, No. x, xxx 20xx, Doi: https://doi.org/.xxxxx, hal. $x-x x$

Submitted: xx July 2020

Revised: xx July 2020

Accepted: xx July 2020

haknya.

Makna konotasi:

Pada tulisan ini mengkonotasikan bahwa "Critical media consciousness" dapat mengembangkan literasi media menjadi lebih kuat lagi dalam mengkritisi terhadap produksi, regulasi dan konten media selain itu "Critical media consciousness" adalah sumber pembentukan ideologi perlawanan dan agen untuk pihak yang tertindas.

Mitos:

"Critical media consciousness" adalah konsep yang lebih kuat dari literasi media untuk membentuk ideologi perlawanan bagi pihak yang tertindas.

Kutipan (4) (Fraley \& Roushanzamir, ibid, Hlm. 128)

\begin{abstract}
"Rational debate is increasingly negated as people lose the opportunities to express opinions; in short, they are effectively denied inclusion to the political process as crucial information disappears."
\end{abstract}

Makna Denotasi:

Para penulis Todd Fraley dan Elli Lester Roushanzamir menyampaikan bahwa perdebatan rasional semakin dihilangkan karena masyarakat semakin kehilangan kesempatan untuk mengekspresikan opininya. Masyarakat ditolak untuk diikutsertakan dalam proses politik karena adanya informasi penting yang menghilang.

\section{Makna konotasi:}

Pada tulisan ini mengkonotasikan bahwa semakin berkurangnya keterlibatan masyarakat dalam proses politik karena kurangnya kesempatan untuk mengekspresikan opini dan terjadinya putusnya informasi yang lengkap.
Mitos:

Masyarakat semakin passif dalam proses politik dan masyarakat tidak mendapat informasi yang utuh.

Kutipan (5) (Fraley \& Roushanzamir, ibid, Hlm. 129)

"To say that critical media consciousness alone cannot always lead to democracy

is to understate the point. Without making the connection of media consciousness

to the larger theoretical framework of critical theory, mass communication

media are used effectively by reactionary movements."

Makna Denotasi:

Para penulis Todd Fraley dan Elli Lester Roushanzamir menyampaikan bahwa pihak yang mengatakan bahwa "Critical media consciousness" saja tidak selalu mengarah pada demokrasi adalah suatu pengecilan arti - Tanpa menghubungkannya saja kepada kerangka teoritis teori kritis yang lebih besar,media komunikasi massa telah digunakan secara efektif oleh gerakangerakan reaksioner.

\section{Makna konotasi:}

Pada tulisan ini mengkonotasikan bahwa "Critical media consciousness" masih belum memiliki andil besar terhadap demokrasi. Meskipun media komunikasi massa sudah digunakan secara efektif oleh gerakangerakan reaksioner.

Mitos:

"Critical media consciousness" masih belum memiliki pengusung untuk menjadi alat demokrasi.

Kutipan (6) (Fraley \& Roushanzamir, ibid, Hlm. 130) 
JURNAL PUBLIPRENEUR: POLITEKNIK NEGERI MEDIA KREATIF Vol.x, No. x, xxx 20xx, Doi: https://doi.org/.xxxxx, hal. $x-x x$

Submitted: xx July 2020

Revised: xx July 2020

Accepted: xx July 2020

"Too often, progressive activists view mass communication and mass media as already compromised institutions, in short taking on a dysfunctional belief in technological determinism." Makna Denotasi:

Para penulis Todd Fraley dan Elli Lester Roushanzamir menyampaikan bahwa aktivis progresif seringkali memandang komunikasi massa dan media massa sebagai institusi yang sudah terkompromikan, mereka mengambil keyakinan disfungsional dalam determinisme teknologi.

Makna konotasi:

Pada tulisan ini mengkonotasikan bahwa aktivis progresif memandang komunikasi massa dan media massa sebagai institusi yang tidak netral.

Mitos:

aktivis progresif menilai komunikasi massa dan media massa sebagai institusi yang tidak netral.

Kutipan (7) (Fraley \& Roushanzamir, ibid, Hlm. 131)

"Critical media consciousness seeks to expand the current concept of media literacy beyond its limited definitions."

Makna Denotasi:

Para penulis Todd Fraley dan Elli Lester Roushanzamir menyampaikan bahwa "Critical media Consciousness" berusaha untuk memperluas konsep literasi media saat ini di luar definisinya yang terbatas.

Makna konotasi:

Pada tulisan ini mengkonotasikan bahwa konsep literasi media saat ini terbatas sehingga membutuhkan "Critical media Consciousness"

Mitos:
Karena media literasi konsepnya terbatas maka "Critical media Consciousness" berusaha untuk memperluas konsepnya.

\section{Analisa Semiotika pada bab 8 Terrorism, Public Relations and Propaganda}

Penulis bab 8 adalah Nancy Snow adalah Profesor Diplomasi Publik di Kyoto University of Foreign Studies di Jepang (Snow. 2020).

Kutipan (8) (Snow, 2013, Hlm. 145)
"Within the U.S. context, propaganda carries a very negative connotation,
even to this day, despite the word's original association with the Reformation period when Pope Gregory XV established a Congregation for the Propagation

of the Faith to promote the Catholic faith against the rise of Protestantism

Makna Denotasi: in northern Europe."

Nancy Snow menjelaskan Dalam konteks AS, propaganda membawa konotasi yang sangat negatif, bahkan hingga hari ini, meskipun kata tersebut terkait dengan periode Reformasi ketika Paus Gregorius XV mendirikan Kongregasi Penyebaran Iman untuk mempromosikan iman Katolik melawan kebangkitan Protestan di Eropa Utara.

Makna konotasi:

Pada tulisan ini mengkonotasikan propaganda dengan konotasi yang sangat negatif, walaupun terkait Kongregasi Penyebaran Iman untuk mempromosikan iman Katolik melawan kebangkitan Protestan di Eropa Utara.

Mitos: 
JURNAL PUBLIPRENEUR: POLITEKNIK NEGERI MEDIA KREATIF Vol.x, No. x, xxx 20xx, Doi: https://doi.org/.xxxxx, hal. $x-x x$

Submitted: xx July 2020

Revised: xx July 2020

Accepted: xx July 2020

propaganda memiliki konotasi yang sangat negatif meskipun diperiode reformasi hal ini bermakna konotasi positif.

Kutipan (9) (Snow, ibid, Hlm. 147)

"The U.S.government doesn't invariably inform and promote the truth while other countries, particularly those led by dictators, always engage in

Makna Denotasi: lies and deceit."

Nancy Snow menjelaskan Pemerintah AS tidak selalu menginformasikan dan mempromosikan kebenaran sementara negara lain, terutama yang dipimpin oleh diktator, selalu terlibat dalam kebohongan dan tipu daya.

Makna konotasi:

Pada tulisan ini mengkonotasikan Pemerintah AS lebih jujur daripada negara lain, terutama yang dipimpin oleh diktator, selalu terlibat dalam kebohongan dan tipu daya.

Mitos:

Pemerintah AS lebih jujur daripada negara yang dipimpin oleh diktator.

Kutipan (10) (Snow, ibid, Hlm. 148)

\footnotetext{
"Like the term propaganda, the public relations industry carries negative associations, especially when associated only with spin and Makna Denotasi: flacking for one's client."
}

Nancy Snow menjelaskan Seperti istilah propaganda, industri PR membawa asosiasi negatif, terutama jika dikaitkan hanya dengan spin dan flacking untuk kliennya.
Makna konotasi:

Pada tulisan ini mengkonotasikan bahwa membandingkan propaganda dengan industri PR juga memiliki asosiasi negatif.

Mitos:

Propaganda dan industri PR sama sama memiliki asosiasi negatif.

Dibawah ini adalah kumpulan mitos yang didapat dari analisa semiotika yang didapatkan dari kedua bab dari buku Media, Terrorism and Theory.

1. Konsep media literasi dirasa masih belum cukup kuat memenuhi kebutuhan masyarakat saat ini sehingga diperlukan alternatif baru dengan mengkonsep kembali teori media literasi.

2. Media menjelma menjadi sebuah kekuatan yang sangat berperan strategis di tengah masyarakat yang perannya diperebutkan oleh banyak pihak.

3. "Critical media consciousness" adalah konsep yang lebih kuat dari literasi media untuk membentuk ideologi perlawanan bagi pihak yang tertindas.

4. Masyarakat semakin passif dalam proses politik dan masyarakat tidak mendapat informasi yang utuh.

5. "Critical media consciousness" masih belum memiliki pengusung untuk menjadi alat demokrasi.

6. aktivis progresif menilai komunikasi massa dan media massa sebagai institusi yang tidak netral.

7. Karena media literasi konsepnya terbatas maka "Critical media Consciousness" berusaha untuk memperluas konsepnya.

8. propaganda memiliki konotasi yang sangat negatif meskipun diperiode reformasi hal ini bermakna konotasi positif. 
JURNAL PUBLIPRENEUR: POLITEKNIK NEGERI MEDIA KREATIF

Vol.x, No. x, xxx 20xx, Doi: https://doi.org/.xxxxx, hal. $x-x x$

Submitted: xx July 2020

Revised: xx July 2020

Accepted: xx July 2020

9. Pemerintah AS lebih jujur daripada negara yang dipimpin oleh diktator.

10. Propaganda dan industri PR sama sama memiliki asosiasi negatif.

\section{Pembahasan}

Kumpulan mitos diatas merupakan hal-hal yang menarik untuk dibahas secara mendalam dengan menggunakan metode triangulasi sumber dengan tujuan bukan mencari kebenaran tapi untuk mendapatkan informasi baru:

1) Mitos: Konsep media literasi dirasa masih belum cukup kuat memenuhi kebutuhan masyarakat saat ini sehingga diperlukan alternatif baru dengan mengkonsep kembali teori media literasi.

Hasil penelitian sebelumnya menyampaikan bahwa media literasi cenderung menghindari perdebatan dan pertanyaan berat sehingga semangat gerakannya menjadi hambar (Lewis \& Jhally. 1998. Hlm 118). Media literasi dianggap sebagai „Silver Bullet"“ (Senjata yang paling ampuh) dilingkungan media dan informasi yang kompleks (Livingstone. 2018). Disini ditemukan bahwa mitos yang didapatkan memiliki kontradiksi karena Livingstone menganggap media literasi dianggap sebagai senjata yang ampuh.

2) Mitos: Media menjelma menjadi sebuah kekuatan yang sangat berperan strategis di tengah masyarakat yang perannya diperebutkan oleh banyak pihak.

Hasil penelitian sebelumnya menyampaikan bahwa Selama dekade terakhir, 'mediatisasi' telah muncul sebagai konsep penting dan kerangka teoretikal untuk mempertimbangkan interaksi antara media, budaya dan masyarakat (Hepp, Hjarvard \& Lundby. 2015. Hlm. 314). Penerapan strategy dalam media digunakan politik Joe
Biden dalam pemilihan presiden 2020 bahwa penerapan strategi media yang lebih tepat menguntungkan Joe Biden ketika dibandingkan dari lawan politiknya (Wang. 2020). Hasil triangulasi menunjukkan bahwa memang media memiliki peran strategis di tengah masyarakat diberbagai bidang meskipun demikian sebesar apa peran strategisnya media ditengah masyarakat dapat menjadi bahan penelitian selanjutnya untuk mendapatkan data berupa quantifikasi.

3) "Critical media consciousness" adalah konsep yang lebih kuat dari literasi media untuk membentuk ideologi perlawanan bagi pihak yang tertindas.

Hasil penelitian sebelumnya menyampaikan bahwa kesadaran kritis (critical consciousness) merupakan alat pembebasan dari komunitas yang tertindas serta menyampaikan konsepsi analisis kritis sosial, pengembangan identitas kolektif, politik efikasi diri, dan tindakan sosiopolitik ( Watts \& Hipolito-Delgado. 2015. Hlm. 848). Sementara disisi lain, penulis tidak mendapat sumber informasi terkait critical media consciousness di media online maupun blogs sehingga disini didapati gambaran bahwa "Critical Media Consciousness" masih berupa tema yang belum menjadi perbincangan dikalangan masyarakat.

4) Masyarakat semakin passif dalam proses politik dan masyarakat tidak mendapat informasi yang utuh.

Hasil penelitian sebelumnya pada tahun 1974 menyatakan bahwa konvensi sosial, adat istiadat, dan norma dimasukkan, bersama dengan pertanyaan politik, yang membuat sejumlah besar orang setuju atau tidak dalam kehidupan publik mereka (Nolle-Neumann. 1974. Hlm. 43). Penulis tidak dapat mendapatkan sumber terkait 


\section{JURNAL PUBLIPRENEUR: POLITEKNIK NEGERI MEDIA KREATIF Vol.x, No. x, xxx 20xx, Doi: https://doi.org/.xxxxx, hal. $x-x x$}

kondisi masyarakat yang semakin passif dalam proses politik. Hal ini ikut mendorong asumsi bahwa mitos ini jarang diperbicarakan.

5) "Critical media consciousness" masih belum memiliki pengusung untuk menjadi alat demokrasi.

Hasil penelitian sebelumnya menggambarkan bahwa critical media literacy berfokus pada kritik ideologi dan analisis politik representasi seperti gender, ras, kelas, dan seksualitas; memasukkan produksi media alternatif; dan memperluas analisis tekstual untuk memasukkan isu-isu konteks sosial, kontrol, dan kesenangan ( Kellner \& Share. 2007. Hlm. 8). Sementara disisi lain, penulis tidak mendapat sumber informasi terkait critical media consciousness di media online maupun blogs sehingga disini didapati gambaran bahwa "Critical Media Consciousness" masih berupa tema yang belum menjadi perbincangan dikalangan masyarakat.

6) aktivis progresif menilai komunikasi massa dan media massa sebagai institusi yang tidak netral.

Hasil penelitian sebelumnya Cendekiawan media secara ekstensif mengkritik defisit demokrasi yang melekat dalam sistem media yang didominasi perusahaan dan sangat dikomersialkan (Carroll \& Hackett. 2006. Hlm 83). Selama perusahaan teknologi diberi insentif untuk memaksimalkan keuntungan, teknologi akan dibangun yang memberikan penghargaan kepada pemegang saham dengan mengorbankan masyarakat (Rosenstein. 2020). Kedua sumber seakan memberikan kesatuan pendapat bahwa terdapat masalah terkait netralitas media massa.

7) Karena media literasi konsepnya terbatas maka "Critical media Consciousness" berusaha untuk memperluas konsepnya.
Hasil penelitian sebelumnya istilah Critical Media Literacy dapat dicirikan sebagai kemampuan untuk merefleksikan kesenangan yang diperoleh dari media massa dan praktik budaya populer, kemampuan untuk memilih secara selektif di antara ikon budaya populer, atau kemampuan untuk menghasilkan teks multimedia sendiri (Alvermann \& Hagood. 2010. Hlm.194). Sementara disisi lain, penulis tidak mendapat sumber informasi terkait critical media consciousness di media online maupun blogs sehingga disini didapati gambaran bahwa "Critical Media Consciousness" masih berupa tema yang belum menjadi perbincangan dikalangan masyarakat.

8) propaganda memiliki konotasi yang sangat negatif meskipun diperiode reformasi hal ini bermakna konotasi positif.

Hasil penelitian sebelumnya menjelaskan bahwa mungkin propaganda menjadi sinonim dengan manipulasi atau penipuan karena metode yang salah digunakan dalam penyebaran doktrin, kepercayaan atau informasi (Sutiu. 2012. Hlm. 123). Ketika dikaitkan dengan virus Corona melanda dunia, pihak berwenang China meluncurkan kampanye propaganda untuk mencoba mengubah pandemi menjadi kemenangan politik bagi Beijing (Ghitis. 2020). Dari sumber yang didapatkan memperkuat mitos bahwa propaganda berkonotasi negatif walaupun penyebaran agama katolik bermakna konotasi positif.

9) Pemerintah AS lebih jujur daripada negara yang dipimpin oleh diktator.

Hasil penelitian sebelumnya bagaimana pemerintah dan perusahaan, dengan menggunakan sistem hubungan masyarakat dan putaran politik yang canggih, memanipulasi opini publik (White. 2005. 
JURNAL PUBLIPRENEUR: POLITEKNIK NEGERI MEDIA KREATIF Vol.x, No. x, xxx 20xx, Doi: https://doi.org/.xxxxx, hal. $x-x x$

Submitted: xx July 2020

Revised: xx July 2020

Accepted: xx July 2020

Hlm. 651). Sementara dalam pemberitaan penulis tidak dapat menemukan tuduhan yang membandingkan pemerintah AS lebih jujur. Tema ini sepertinya tidak menjadi pembicaraan di media.

10) Propaganda dan industri PR sama sama memiliki asosiasi negatif.

Hasil penelitian sebelumnya menggambarkan bahwa peran praktisi PR ketika mereka mencoba untuk menetapkan kebenaran tertentu dan mengubah hubungan kekuasaan / pengetahuan (Motion \& Leitch. 2007. Hlm. 266). Dalam bisnis public relations merupakan upaya yang melalui strategi yang kompleks untuk mendapat citra yang baik kepada masyarakat (Haileysus. 2020).

\section{Kesimpulan}

Penelitian ini berhasil mengumpulkan beberapa mitos dari buku Media, Terrorism and Theory. Berbagai mitos terkait critical media consciousness ternyata menjadi mitos yang terlihat seperti hanya dibicarakan dalam buku ini. Berdasarkaan validasi melalui triangulasi sumber didapatkan bahwa jargon critical media consciousness terbukti tidak dibicarakan oleh akademisi lain maupun media massa. Jargon critical media consciousness Nampak kabur dibalik jargon critical media literacy ataupun critical consciousness. Hal ini mungkin terkait keterbaruan jargon critical media consciousness yang diusung dalam buku ini. Hal yang lain dapat menjadi pertimbangan bahwa kepakaran dari penulis bab 7 Critical Media Theory, Democratic Communication, and Global Conflict Todd Fraley \& Ellie Lester Roushanzamir harus mendapatkan evaluasi lebih mendalam tanpa menjustifikasi kepakaran dari penulis bab tersebut.
Dalam sisi lain mitos-mitos pada bab 8 Terrorism, Public Relations, and Propaganda yang ditulis oleh Nancy Snow tampak banyak dibicarakan oleh akademisi lainnya tercermin dari jurnal-jurnal bereputasi yang memuat tema serupa. Kemudian pada media massa juga membicarakan hal yang serupa pada mitos yang ditampilkan pada bab yang ditulis oleh Nancy Show. Namun ada satu mitos yang muncul sepertinya tidak terlalu dibicarakan oleh media massa meskipun dibicarakan akademisi yaitu mitos terkait tudingan bahwa pemerintah Amerika Serikat tidak selalu jujur dalam melakukan pemberitaan. Namun hal ini sepertinya menjustifikasi mitos yang digambarkan oleh Nancy Snow terkait strategi Public Relations Amerika Serikat yang kompleks sehingga dapat menciptakan citra positif yang baik dilingkungan media massa internasional.

\section{Saran}

Sebagai semangat konsisten dalam pendekatan penelitian teori kritis kiranya tulisan ini bisa mendapatkan evaluasi dan bisa menjadi ruang diskusi. Penulis memahami kiranya pandangan kritis akan muncul dengan penggunaan analis semiotika Roland Barthes pada buku Media, Terrorism and Theory karena pada umumnya analis semiotika Roland Barthes digunakan pada karya sastra seperti novel atau puisi. Selain itu penulis juga merasakan bahwa analis semiotika pada buku ini cukup terbatas karena cakupan mitos yang diuji hanya terbatas pada dua bab yaitu bab 7 dan bab 8 . Buku ini sendiri memiliki 10 bab yang kemudian akhirnya menimbulkan pertanyaan apakah mitos yang dikumpulkan dalam penelitian ini bisa mewakili seluruh mitos didalam buku ini. Peneliti sangat terbuka untuk mendorong penelitianpenelitian lanjutan terkait buku ini untuk mendapat pandagan kritis terhadap suatu 
JURNAL PUBLIPRENEUR: POLITEKNIK NEGERI MEDIA KREATIF

Vol.x, No. x, xxx 20xx, Doi: https://doi.org/.xxxxx, hal. $x-x x$

Submitted: xx July 2020

Revised: xx July 2020

Accepted: xx July 2020

buku yang bertema global, keamanan, dan media seperti buku ini.

\section{Daftar Referensi}

\section{Books}

Anandaam Kavoori \& Todd Fraley. (2006). Media, Terrorism and Theory, a reader. Rowman \& Littlefield Publishers.

Gearóid Ó Tuathail. (1996). Critical GeopoliticsThe Politics of Writing Global Space. Routledge London

Pickering S. (2017) Popular Geopolitics. In: Understanding Geography and War. Palgrave Macmillan, New York.

W. Lawrence Neuman. (2013). Metode Penelitian Sosial: Pendekatan Kualitatif dan Kuantitatif. Pearson Education.

\section{Book Chapter}

Nancy Snow. (2013) Terrorism, Public Relations, and Propaganda. In A. Kavoori \& T. Fraley. (Eds). Media, Terrorism and Theory, a reader. Rowman \& Littlefield Publishers

Douglas Kellner \& Jeff Share. (2007). Critical Media Literacy, Democracy, and the Reconstruction of Education. In D. Macedo \& S.R. Steinberg (Eds.), Media literacy: A reader (pp. 3-23). New York

Todd Fraley \& Ellie Lester Roushanzamir. (2013). Critical Media Theory, Democratic Communication, and Global Conflict. In A. Kavoori \& T. Fraley. (Eds). Media, Terrorism and Theory, a reader. Rowman \& Littlefield Publishers

\section{Journals}

Airdan White. (2005). Truth, Honesty \& Spin. Journal Democratization. Vol. 122005 P. 651-667.

Anderson Daniel Sudarto, Jhony Senduk \& Max Rembang. (2015). Analisis Semiotika film ,alangkah lucunya negeri ini““. Journal Acta Diourna Vol IV. No.1 Tahun 2015.

Andreas Hepp, Stig Hjarvard \& Knut Lundby. (2015). Mediatization: theorizing the interplay between media, culture and society. Media, Culture \& Society 2015, Vol. 37(2) 314-324

Bachtiar, S Bachri. (2010). Meyakinkan validitas data melalui triangulasi pada penelitian kualitatif. Jurnal Teknologi Pendidikan 2010.

Bambang Mudjiyanto \& Emilsyah Nur. (2013). Semiotika dalam metode penelitian komunikasi. Jurnal Penelitian Komunikasi, Informatika dan Media Massa PEKOMMAS Vol 16 No.1 April 2013.

Cristina Lucia Sutiu. (2012). Propaganda: How good word went wrong. Agathos: An International Review of the Humanities \& Social Sciences . 2012, Vol. 3 Issue 2, p122130

Didi Sukyadi. (2013). Dampak Pemikiran Saussure pada perkembangan Linguistik dan Ilmu lainnya. Parole Vol. 3 No. 2 Oktober 2013.

Elisabeth Noelle-Neumann. (1974). The Spiral of Silence a Theory of Public Opinion, Journal of Communication, Volume 24, Issue 2, June 1974, Pages 4351.

Justin Lewis \& Sut Jhally. (1998). The Struggle Over Media Literacy, Journal of Communication, Volume 48, Issue 1, March 1998, Pages 109-120. 
JURNAL PUBLIPRENEUR: POLITEKNIK NEGERI MEDIA KREATIF

Vol.x, No. x, xxx 20xx, Doi: https://doi.org/.xxxxx, hal. $x-x x$

Submitted: xx July 2020

Revised: xx July 2020

Accepted: xx July 2020

Roderick J. Watts \& Carlos P. HipolitoDelgado. (2015). Thinking ourselves to liberation?: Advancing Sociopolitical Action in Critical Consciousness. Urban Rev (2015). 47: 847-867.

William K. Carrol \& Robert A. Hackett. (2006). Democratic Media Activism through the lens of social movement theory. Media, Culture \& Society. Vol. 28(1): 83-104

\section{Blogs}

Frida Ghitis. (2020). Why China's Corona Virus propaganda campaign has come up short. World Politics Review. https://www.worldpoliticsreview.com/articl es/29136/why-china-s-coronaviruspropaganda-campaign-has-come-up-short

Samson Haileyesus. (2020). 101 Public Relations Strategies, tips and Examples. Small Business Trends. https://smallbiztrends.com/2020/03/publicrelations-strategies-tips-examples.html

Sonia Livingstone. (2018). Media Literacy: What are the challenges and how can we move towards a solution. London School of Economics and Political Science. https://blogs.lse.ac.uk/medialse/2018/10/25/ media-literacy-what-are-the-challengesand-how-can-we-move-towards-a-solution/

Jenny Wang. (2020). Why Former VP Biden's Media Strategy is working. PRNEWS.

https://www.prnewsonline.com/mediastrategy-Biden-Trump

Justin Rosenstein. (2020). Social Media's Business Model is a threat to democracy its time to change it. El Pais. https://english.elpais.com/opinion/2020-1030/social-medias-business-model-is-athreat-to-democracy-its-time-to-change- it.html

\section{Sumber internet lainnya}

East Carolina University. (2020). Dr Todd Fraley. https://honors.ecu.edu/about/facultystaff/dr-todd-fraley/

$\begin{array}{llrl}\text { Academia. } & (2020) & \text { Elli } & \text { Lester } \\ \text { Roushanzamir } & \text { Curriculum } & \text { Vitae }\end{array}$ https://uga.academia.edu/ElliLesterRoushan zamir/CurriculumVitae

Nancy Snow. (2020). Nancy Snow Bio. https://nancysnow.com/bio 